\title{
MODERN APPROACH TO MATERIALS CURRENTLY USED IN TRANSMISSION GEARS
}

The article discusses the materials currently used for transmission elements as an alternative to traditionally used bearing, alloy and special steels, for carburizing and for improvement. The material properties were presented, the possibilities of their implementation were discussed, as well as the advantages and disadvantages of their application. A comparative analysis of the proposed materials was made. The possible development directions have been indicated.

\section{INTRODUCTION}

Nowadays, we are living in era of sophisticated technology. Engineers are looking for cheaper, lighter and more durable solutions while maintaining the high degree of design perfection. There is a need to design and manufacture gearboxes with light and precision cut gears, durable bearings and shafts. It involves to produce parts made from materials of high strength, light weight, which have the ability to carry extremely large loads. In the same time transmitting the extremely large loads should take place in environment of high circumferential speeds, low level of noise and vibrations.

Gear wheels play vital role in power gearboxes. Due to this, high speed gears have to be of high quality to maintain contact and keep contact stresses within the limits. Gear wheels should be characterized by high resistance to fatigue wear, structural stability when working at elevated temperatures and the resistance of the surface layer to pitting wear. The gears of modern drive units operate in extremely unfavorable conditions, transferring very high torques, working with rotational speeds of up to several tens of thousands of revolutions per minute. In addition, emergency situations like a lack of lubricant should be anticipated.

Currently, it is moving away from widely used various types of steel as a material for transmission components. In modern gear trains are used materials that enable weight reduction while ensuring high reliability of the structure.

The present work deals with the problem of the optimization of modern materials used for transmission gear parts.

\section{MATERIALS CURRENTLY USED FOR TRANSMISSION COMPONENTS}

The article indicates selected currently used material solutions used for gear components such as gear wheels, rollers and bearings.

\subsection{Aluminum}

Aluminum in gear transmissions is used as material for gears. This application is designed to ensure high durability of gears, corrosion resistance and ensure weight reduction. The disadvantage of aluminum is the high coefficient of thermal expansion compared to steel [2]. Aluminum is also easy to process, ductile, it has nonmagnetic properties; it is plastic, so it can be molded into any shape.
Unfortunately, pure aluminum doesn't have a high tensile strength. The tensile strength of pure aluminum is around $90 \mathrm{MPa}$, Young's modulus (GPa) - 70.3 MPa.

Aluminum gears offer high strength, provide smoother operation, longer life and quieter operation; they are resistant to wear and ensure maximum efficiency. The another advantage of aluminum gears is fact, that they can have different shapes. [8]

\subsection{Aluminum alloys}

Aluminum alloys are not widely used as the material from which gears are made, although aluminum is readily available as a structural metal, in a technically clean condition has too high mechanical strength for use in parts subjected to loads. In the case where aluminum is suitably alloy, its tensile strength may be similar to that of steel. The density is about $1 / 3$ of the density of steel, and the thermal conductivity corresponds to about $1 / 3-1 / 2$ of the thermal conductivity of copper. These properties allow for the wide use of aluminum alloys, among others in worm gears. Alloys suitable for the formation of gears are available in cast or forged form, and tensile strength can be obtained by heat treatment [1]. Super high strength aluminum alloys provide the highest mechanical strength of all currently aluminum alloys matching that of most of steel and titanium alloys. Super high strength alloys offer:

- a tensile strength of $620-850 \mathrm{MPa}$,

- a yield strength from 560 up to $767 \mathrm{MPa}$,

- Brinell's hardness from 150 to $220 \mathrm{HB}$

- good ductility,

- elongation up to $11 \%$,

- corrosion resistance.

Nowadays, super high strength aluminum alloy are also widely used in gearboxes. [3]

\section{Aluminum alloy 7068}

Aluminum 7068 is a light-weight metal with a bright silvery luster. This metal along with its alloys are in high demand worldwide. It was designed as a higher strength alternative to aluminum. It also provides the highest mechanical strength of all aluminum alloys.

The chemical composition of aluminum 7068:

- Zinc, Zn - 8.3\%;

- Magnesium, $\mathrm{Mg}-3 \%$;

- Copper, Cu- 2.4\%;

- Iron, Fe- 0.15\%;

- Zirconium, Zr - 0,15\%;

- Silicon, Si - 0.12\%; 
- Manganese, $\mathrm{Mn}-0.1 \%$;

- Titanium, $\mathrm{Ti}-0.1 \%$;

- Chromium, $\mathrm{Cr}-0.05 \%$;

- Aluminum, Al-remainder [5].

Aluminum alloys 7068 are used as a material for gears, among others, in gears in motorcycles. The use of alloys reduces weight, improves work efficiency, reduces the amount of fuel consumed and reduces emissions.

Properties of the alloy:

- corrosion resistance;

- faster heat dissipation, more silent operation compared to high carbon steel used in gear transmissions;

- heat treatable wrought alloy with good fatigue strength;

- good anodizing response;

- high thermal conductivity - $190 \mathrm{~W} / \mathrm{m}-\mathrm{K}$;

- a tensile strength of $641 \mathrm{MPa}$;

- a yield strength of $690 \mathrm{MPa}$;

- elongation up to $8 \%$.

The gears made of 7068 aluminum have almost 3 times less mass than those traditionally used. Aluminum alloy consumption is higher than when using high carbon steel. The disadvantage is also the high cost. [4]

\section{Aluminum alloy 2024}

The aluminum alloy 2024 heat-treatable aluminum alloy with copper as the primary alloying element.

The chemical composition of aluminum 2024:

- Silicon, Si - 0.5\%;

- Iron, Fe - 0.5\%;

- Copper, $\mathrm{Cu}-3.8-4.9 \%$;

- Manganese, $\mathrm{Mn}-0.3-0.9 \%$;

- Magnesium, $\mathrm{Mg}-1.2-1.8 \%$;

- Chromium, $\mathrm{Cr}-0.1 \%$;

- Zinc, Zn-0.25\%;

- Titanium, Ti - 0.15\%;

- Aluminum, Al - Remainder. [7]

Aluminum 2024 is used in gears as a material for gears. It has high strength, corrosion resistance. It is used in applications requiring high strength to weight ratio, as well as good fatigue resistance. Aluminum alloy 2024 offers:

- an ultimate tensile strength about $118-469 \mathrm{MPa}$,

- a yield tensile strength of $469 \mathrm{MPa}$;

- hardness up to $170 \mathrm{HV}$;

- Modulus of elasticity $73.1 \mathrm{GPa}$;

- elongation up to $20 \%$;

- density 2,78 $\mathrm{g} / \mathrm{cm}^{3}$;

- shear modulus $28 \mathrm{GPa}$;

- thermal conductivity $121 \mathrm{~W} / \mathrm{m}-\mathrm{k}$. [6]

\subsection{Bronzes}

Bronzes have good sliding properties, therefore they are widely used material used for gears, are extremely stable, provide the machine with optimal working properties, disadvantages: weight and high price.

\section{Aluminum bronzes}

Aluminum bronzes type 2 are used as materials for the following: gears, bearings and bushings. Aluminum bronzes possess innate pitting resistance. They are used where resistance to: rust, erosion is required and waterproofness is necessary.

The chemical composition of Aluminum bronzes type 2:

- Copper, $\mathrm{Cu}-80 \%$;

- Aluminum, $\mathrm{Al}-8-10.5 \%$;

- Iron, $\mathrm{Fe}-2.5-3.5 \%$;
- Nickel, $\mathrm{Ni}-1-3 \%$;

- Manganese, $\mathrm{Mn}-<1.5 \%$

The most important mechanical properties:

- tensile strength - from $490 \mathrm{~N} / \mathrm{mm}^{2}$;

- elongation about 20\%;

- Brinell hardness $120 \mathrm{HB}$. [9].

Aluminum is the main strengthening element and it contents normally ranges from 8 to $13 \%$. At the top end of the range, hardness figures of $30-44 \mathrm{HRC}$ are possible. However, at these very high hardness's, the ductility is reduced to $1 \%$.

\section{Nickle bronzes}

Nickel bronze is used as a coating for gear wheels and as material for bearings. It has a high resistance to surface wear. It also has a high resistance to corrosion, abrasion and impact. The nickle bronzes are used for production of highly loaded elements. Nickel is added in quantities ranging from 1-7\% [10]. Nickel is soluble in copper at lower levels and is added in conjunction with iron. Its presence improves the corrosion resistance and increases the mechanical strength. It also helps with the erosion resistance in high velocity water flow (high resistance to impingement attack/erosion corrosion at a seawater velocity of up to $4.3 \mathrm{~m} / \mathrm{s}$ ). The nickel aluminum bronzes offer a wide range of mechanical strength across the family of alloys, the tensile strength is about $650 \mathrm{MPa}$.

It works well in atmospheric and immersion conditions- General corrosion < 0.025-0.05 mm/year; pitting corrosion resistance is at good level, particularly with attention to correct alloying and heat treatment [11].

\section{Magnesium bronze}

Magnesium bronze C86300 (SAE 430B) Manganese Bronze is used as a material almost exclusively in double helical gears for mill cutting machines. This alloy is tough and corrosion resistant; it is also ideal for high load, low speed applications that require a combination of outstanding wear characteristics and high bearing strength. Manganese bronze alloy is not heat-treatable, needs reliable lubrication and should be used in conjunction with hardened shafts. The lead in the alloy's makeup improves machinability without materially affecting its mechanical properties.

Chemical composition:

- Copper, Cu-60-66\%;

- Tin, Sn-0,2\%;

- Lead, $\mathrm{Pb}-0.2 \%$;

- Zinc, Zn-22- 28\%;

- Iron, $\mathrm{Fe}-2-4 \%$;

- Nickel, $\mathrm{Ni}-1 \%$

- Aluminum, Al-5- 7.5\%;

- Manganese, $\mathrm{Mn}-2.5-5 \%$.

Mechanical properties:

- tensile strength $785 \mathrm{MPa}$;

- yield strength $427 \mathrm{MPa}$;

- elongation - $14 \%$.

- Modulus of elasticity in tension - $97900 \mathrm{MPa}$;

- thermal conductivity $-20^{\circ} \mathrm{C}$. [17]

\section{Tin bronzes}

Tin bronze alloy is characterized by elasticity and resistance to abrasion and corrosion. It subjects to soldering, welding and cold working. The alloy is used for production of wear-resistant parts.[12] Tin bronze is used where there is a need for slipping between the toothed wheels; provides high load capacity; has a low coefficient of friction; good thermal conductivity, high abrasion resistance.

The family of tin bronze alloys includes such alloys as:

- C90300. 
- C90500;

- C90700;

- C90810;

- C91000;

- C91100;

- C91300;

- C91600;

- C91700.

In the worm gears, tin bronze C90700 (SAE65) High Tin

Bronze is used as the material for the gears. It is necessary here to carry heavy loads and high durability. [10]

The chemical composition of Tin Bronze C90300:

- Cooper, Cu-86- 89\%;

- Tin, $\mathrm{Sn}-7.5-9 \%$;

- Lead, $\mathrm{Pb}-0.3 \%$;

- Zinc, Zn-3-5\%;

- Nickel -1\%;

- Iron, $\mathrm{Fe}-0.2 \%$

- Stibnite, $\mathrm{Sb}-0,2 \%$;

- Phosphorus, P-1,5\%;

- Sulfur, $S-0.05$

- Aluminum, $\mathrm{Al}-0.005 \%$

- Silicon, $\mathrm{Si}-0.005 \%$.

Mechanical properties of C90300:

- density $8.8 \mathrm{~g} / \mathrm{cm}^{3}$ at $20^{\circ} \mathrm{C}$;

- thermal conductivity $75 \mathrm{~W} / \mathrm{m}-\mathrm{K}$

- elongation up to $22 \%$;

- modulus of elasticity in tension- $96500 \mathrm{MPa}$;

- elastic modulus $110 \mathrm{GPa}$;

- shear modulus $41 \mathrm{GPa}$;

- yield tensile strength $150 \mathrm{MPa}$;

- Brinell's hardness 70 B. [18]

\section{Aluminum nickle bronzes}

Aluminum nickle bronzes has good to excellent corrosion resistance. They are good hot formability. Fabricated by hot forming and forging. Applications in gearboxes: nuts, bolts and shafts.

Nickel aluminum bronzes are available in a combination of properties:

- high strength;

- excellent wear and galling resistance

- non-sparking;

- low magnetic permeability;

- high corrosion resistance;

- high resistance to cavitation;

- good stress corrosion properties;

- good cryogenic properties;

- damping capacity twice that of steel;

- high resistance to biofouling.

- protective oxide surface film that has the ability to self-repair [11].

The chemical composition:

- Aluminum, Al - 9-11\%;

- Copper, $\mathrm{Cu}-78-85 \%$;

- Iron, $\mathrm{Fe}-2-4 \%$;

- Manganese, $\mathrm{Mn}-1.5 \%$;

- Nickle, Ni - 4-5.5\%;

- Silicone, Si $-0.25 \%$

- Tin, $\mathrm{Sn}-0,2 \%$;

- Zinc, Zn-0.3\%. Mechanical properties:

- hardness, Rockwell -94B;

- density $7.7 \mathrm{~g} / \mathrm{cm}^{3}$;
- yield tensile strength- $470 \mathrm{MPa}$;

- ultimate tensile strength- $760 \mathrm{MPa}$;

- elongation of $10 \%$;

- Modulus of elasticity - $115 \mathrm{GPa}$;

- thermal conductivity - $37.7 \mathrm{~W} / \mathrm{m}-\mathrm{K}$ [14].

\subsection{Magnesium Alloys}

Magnesium alloys are light weight and have high machinability. In transmission gear trains, the magnesium alloy AZ31 with high strength properties is used as the material for gears.

Mechanical properties of Magnesium alloy AZ31:

- elongation about $15 \%$;

- Brinell's hardness 73 HB,

- modulus of elasticity of $45 \mathrm{GPa}$;

- tensile strength up to $290 \mathrm{MPa}$;

- shear modulus $17 \mathrm{GPa}$;

- elastic modulus $44.8 \mathrm{GPa}$;

- shear strength $130 \mathrm{MPa}$;

- yield strength $200 \mathrm{MPa}$;

- thermal conductivity $-96^{\circ} \mathrm{C}$.

Chemical composition:

- Aluminum, Al -2.5- 3.5\%;

- Zinc, Zn-0.7- 1.3\%;

- Manganese, $\mathrm{Mn}-0.2 \%$;

- Silicon, Si - 0,05\%;

- Cooper, $\mathrm{Cu}-0.05 \%$;

- Iron, Fe-0.005\%;

- Nickel, $\mathrm{Ni}-0.10 \%$;

- Magnesium, Mg-Balance.

Magnesium AZ31 has good machinability. Disadvantage is fact, that it is flammable, so extreme care should be taken while performing this process. A lubricant is used to perform machining process. The machinist is required to constantly monitor the operation with a magnesium fire arresting kit. [13]

\subsection{Brass alloys}

Brass as material for gears - this metal has a low price, is resistant to corrosion and is easy to process; advantages: high strength and hardness; good electrical conductivity. Their high conductivity with good corrosion resistance makes them ideal for the production of electrical equipment. Brass is widely used in low-cost gears of commercial quality. Brass gears are also used in locomotives, clocks and in all heating industries.

Brass alloy C3604 is used for wheel gears in transmission gear trains. C3604 brass row has high strength, good ductility, suitable for cold and hot processing good welding resistance and corrosion resistance, good weldability, corrosion resistance, electrical conductivity, good thermal conductivity, high corrosion resistance of air and water, and has good plasticity, easy to cold and hot working, easy welding, forging and tin, no stress corrosion cracking tendency

- The chemical composition is presented below:

- Cooper, $\mathrm{Cu}-57-61 \%$;

- Lead, Pb- 1.8-3.7\%;

- Iron, $\mathrm{Fe}-<0,5 \%$;

- Tin $\mathrm{Sn}+$ Iron, $\mathrm{Fe}<1,2 \%$.

The mechanical properties:

- tensile strength about $335 \mathrm{MPa}$

- Young's modulus- $96 \mathrm{MPa}$;

- Vivtorinox hardness HV $(\geq 0.5): \geq 80$

- tensile strength: $440 \mathrm{MPa}$;

- elongation $10 \%$. [16] 


\subsection{Ceramics}

Ceramics used as a coating or material for gears and bearings. Ceramics are ideal for small transmissions, where high wear resistance is required. Ceramics specializes in applications in which metal alloys traditionally fail. Ceramics are also non-magnetic and bio-compatible. Thanks to this, they are perfectly suited for biotechnology and vacuum environments. Ceramics are well insulated against electricity together with heat and have anti-friction properties. The disadvantage of ceramics is fact, that it have a low cracking strength.

\section{AlSiC Metal Matrix Composite Ceramics}

Currently, the new discovery is the use of AlSiC ceramics. AISiC properties: low weight, high stiffness, low thermal expansion; high thermal conductivity, excellent mechanical damping. We distinguish the following alloys from the AISiC family: AL70/SiC30, AL60/SiC40, AL50/SiC50, AL40/SiC60.

The mechanical parameters of AISiC:

- Young's Modulus from 125 to $230 \mathrm{MPa}$;

- flexural strength up to $290 \mathrm{MPa}$;

- thermal conductivity $140-180 \mathrm{~W} / \mathrm{m}-\mathrm{K}$;

- tensile strength up to $420 \mathrm{MPa}$ [16].

\section{Ceramic hybrid bearing}

Ceramic Hybrid Bearings have steel races and ceramic balls.

Ceramic balls are usually made of:

- Silicon Nitride $\left(\mathrm{Si}_{2} \mathrm{~N}_{4}\right)$;

- Alumina Oxide $\left(\mathrm{Al}_{2} \mathrm{O}_{3}\right)$, but not applicable for high speed bearings;

- Zirconia Oxide $\left(\mathrm{ZrO}_{2}\right)$, but not applicable with high friction solutions;

- Silicon Carbide (SiC), but not applicable for high speed bearings.

Ceramic Balls are suitable for applications where high loads, high speeds and extreme temperatures are factors. Where we except long life and the minimal lubrication. Due to the fact that, ceramic is a glass like surface it has an extremely low coefficient of friction and it makes it ideal for applications seeking to reduce friction. Ceramic is non-porous, non-magnetic, non-corrosive and lighter than steel. In ball form, ceramic balls are also harder than steel and because ceramic balls are non-porous they are virtually frictionless and capable of spinning faster than steel balls. As a results that properties increased bearing life. Thermal properties are better than steel balls resulting in less heat generation at high speeds.

Advantages of using bearing with ceramics balls:

- in solutions where: high loads, high speeds and extreme temperatures are indispensable elements of work;

- increased bearing life;

- decreased down time;

- need only small amount of lubrication;

- no cold welding between ceramic balls and races;

- high efficiency;

- high hardness;

- high Modulus of Elasticity;

- low density;

- low coefficient of thermal expansion;

- high electrical resistivity;

- low dielectric constant;

- no response to magnetic fields;

- low weight;

- small size.

\section{Silicon nitride ball bearings}

Material used for ball bearings is silicon nitride $\left(\mathrm{Si}_{2} \mathrm{~N}_{4}\right)$. Ceramic ball bearings are rounder than the steel bearings. They have smoother surface and more uniform size, therefore friction is reduced and that can contribute to a less energy required to turn the cranks or spin the wheels. Ceramic bearings are also harder than steel bearings (up to $30 \%$ ), which improves durability, and they also don't rust so less maintenance should be required.

The properties of silicon nitride ball bearings:

- density $3,2 \mathrm{~g} / \mathrm{cm}^{3}$;

- Vickers hardness: 1550;

- Elastic Modulus $320 \mathrm{GPa}$;

It is better to use the silicon nitride ball bearings instead of steels because of:

- smoother surface and better geometry;

- lower thermal expansion;

- improved corrosion and electrical resistance;

- lighter weight;

- they are harder and stiffer. [19].

\section{COMPARATION OF MATERIAL PROPERTIES}

Aluminum alloys seem to be promising materials for gear wheels that could replace constantly under specific operating conditions. The biggest advantage is the possibility of free forming of aluminum wheels (use for example as planetary wheels with an outline of epicycloids), because the aluminum is flexible and plastic. It also have much lower weight compared to steel and what is more aluminum is corrosion resistance, nonflammable, non-toxic, environmentally friendly, completely recyclable as secondary sera, which is extremely important in connection with ecological trends. The biggest disadvantage, however, is the low tensile strength.

Aluminum alloys type 2024 are one of the most durable aluminum alloys, they are also characterized by extremely high corrosion resistance; however, they have very low resistance to oxidation; besides that, they are not suitable for welding and hard workable.

Aluminum alloys 7068 exhibit extraordinary tensile strength, what is more offer an attractive combination of high strength and reduced weight. besides they have good ductility and corrosion resistance.

Depending on the intended use of the gear unit, aluminum alloys can meet specific requirements regarding the operating conditions of the transmission. Undoubtedly, these are cost-intensive, when we plan to use aluminum alloys

Advantages of the use of gears made of bronze alloys are their resistance to corrosion, abrasion, resistance to wear, pitting wear, hardness and ease of forming. Changing the alloy additions, the desired material properties can be achieved. Unfortunately the use of bronze alloys should be ruled out in solutions requiring a reduction in the weight of gears.

Tin brushes are high-quality bearing materials resistant to abrasion. In comparison to tin bronzes, aluminum bronzes, in addition to better strength and plastic properties, have better chemical resistance and heat resistance, better liquidity and less tendency to segregate. They are perfect as materials from which parts of heavily loaded machines are made, which are exposed to corrosion and abrasion.

The most modern group of materials, hitherto not used on a large scale, is ceramics. The use of ceramics is now limited to bearing balls and bearings as a whole element and rarely to gears. Steel bearings (beside high-speed bearings) can be successfully replaced with hybrid ceramic bearings of the same size and design. In this solution, the new bearings provide better kinematic behavior 
and lower operating temperatures. As a result, the life of hybrid ceramic bearings in the machine becomes three times longer than the life of steel bearings. Hybrid ceramic bearings provide higher rotational speeds at lower friction. reduced friction and a lower temperature increase allow to increase the speed of rotation. In addition, the lower weight of the hybrid balls allows for rapid acceleration and deceleration.

Due to the smoothness of bearings, they generate less vibrations than bearings made entirely of steel, which reduces the noise level during their operation.

In addition, they provide low operating costs - it is associated with their long life, simple operation and easy assembly.

Making a researches on ceramics can bring results and in the future, broaden the spectrum of ceramic use as a material, which covers the components of the gear. Undoubted disadvantage here is the fragility of ceramics, which affects the inability to use it in gears, especially those working under heavy load, where high gear ratio is required, specific operating conditions prevail, wheel gears are moving at high speed.

\section{SUMMARY}

Making a comparative analysis of selected and described in the previous chapter materials, it would be necessary to analyze all the properties of materials, at the same time taking into account aspects that are important for the engineer during designing the transmission. It is difficult to clearly determine which material would be the most optimal. Some of the materials proposed in the literature were only subjected to numerical analysis, which means that experimental studies that would have verified the level of applicability of the proposed application have not yet been carried out. It would be necessary to carry out experimental researches, which will confirm whether in fact the change of traditional material to unconventional will bring planned results.

Depending on the expected result, among others: reduction of operating costs, reduction of transmission weight, improvement of strength parameters, the material should be optimally selected. One should remember about limitations related to the parameters of a given material, as well as the possibilities of its production, and finally also its processing.

In connection with researches and constant development, among others work on ceramics, it seems that in the coming years in specific solutions, requiring specific conditions, steel can be replaced by other composite materials. At present steel is most often replaced by other alloys, which are used for gear housing, where the materials need to be lighter and more resistant to work temperature and corrosion.

Undoubtedly, it is worth looking for an alternative to the use of steel, to improve the efficiency of the transmission and extend its service life.

\section{BIBLIOGRAPHY}

1. Keerthi M, Sandya K, Srinivas K., Static \& Dynamic Analysis of Spur Gear using Different Materials, International Research Journal of Engineering and Technology (IRJET), Volume: 03 Issue: 01, Jan-2016
2. Bell. P. Ch., Power Transmission, Springer, s. 52-53.

3. http://www. baienwei.net/products-index/Super-High-StrengthAluminum-Alloys.html

4. Venugopal N., Ramanathan V., Experimental investigation on performance of aluminum alloy 7068 gears in a motorcycle gearbox, International Journal of Mechanical And Production Engineering, ISSN: 2320-2092, Volume- 5, Issue-7, Jul.-2017

5. https://www.azom.com/article.aspx?ArticlelD $=8758$

6. Davis J. R., Corrosion of Aluminium and Aluminium Alloys, ASM International

7. https://www.unitedaluminum.com/united-aluminum-alloy-2024/

8. https://www.indiamart.com/ashokagears/gear-material.html

9. http://khkgears.net/gear-knowledge/introduction-togears/materials-gears-heat-treatment/

10. Watson H. J., Modern Gear Production, Elsevier, 2013

11. Richardson I., Guide to Nickel Aluminium Bronze for Engineers, Copper Development Assosiation, January 2016

12. http://www.metallexpres.pl/oferta/braz

13. http://www.goodfellow.com/E/Magnesium-alloy-AZ31.html

14. http://elginfasteners.com/resources/materials/materialspecifications/aluminum-nickel-bronze

15. https://www.indiamart.com/ashokagears/gear-material.html

16. Bansal M., Sindhu N., Anand S., Structural And Model Analysis Of A Composite Material Differential Gearbox Assembly, ljesrt International Journal Of Engineering Sciences \& Research Technology, 2016

17. https://www.dura-barms.com/bronze/manganesebronze/c86300.cfm\#physical

18. https://www.concast.com/c90300.php

19. https://www.bocabearings.com/general/full-ceramic-andceramic-hybrid-bearings

\section{Nowoczesne podejście do materiałów stosowanych obecnie na elementy przekładni zębatych}

$W$ artykule omówiono materiaty wspótcześnie stosowane na elementy przekładni jako alternatywa dla tradycyjnie stosowanych stali łożyskowych, stopowych, specjalnych, do nawęglania oraz do ulepszania. Przedstawiono wlaściwości materiałów, omówiono możliwości ich implementacji, a także wskazano zalety $i$ wady, wynikajace $z$ ich zastosowania. Dokonano analizy porównawczej zaproponowanych materiałów. Wskazano możliwe kierunki rozwoju.

Authors:

mgr Joanna Matczak - Lodz University of Technology, Faculty of Mechanical Engineering, Department of Vehicles and Fundamentals of Machine Design

mgr Kamil Matczak - Lodz University of Technology, Faculty of Mechanical Engineering, Department of Vehicles and Fundamentals of Machine Design

JEL: L96 DOI: 10.24136/atest.2018.139

Data zgłoszenia: 2018.05.23 Data akceptacji: 2018.06.15 